\title{
MESSINIAN BIOSTRATIGRAPHY BASED ON FORAMINIFERA AND OSTRACODES IN IONIAN ZONE OF ALBANIA
}

\author{
K. BULI', S. PRILLO ${ }^{1}$, N. BULI', L. KUMATI' AND R. ROQI'
}

\section{ABSTRACT}

Messinian biostratigraphy based on foraminifera and Ostracodes was studied in several surface sections within Peqin-Durres region. The sections are located in the eastern and northwestern part of the Peri-Adriatic Foredeep (PAF) of Albania (Fig.1). The Thartor section is located more or less in the center of the region studied.

Its Messinian sediments in particular late Messinian one are well exposed and just in this place they represent the boundary of great differences between these sediments and those that could be occurred towards east or towards south. Firstly, here well distinguished the preevaporitic sequence which very rapidly wedge-out towards southeast. Secondly, here is the latest southeast boundary of gypsum blocks occurrence. Moreover in this section the lack of "lago-mare" biofacies is apparently owing to its erosion. Towards northern and western sections the lower boundary of "lago-mare" biofacies is well determined lithologically and faunistically. Towards southeast and eastern sections this boundary determined also by first occurrence of Cyprideis, Candona etc., as above but it seems to be not synchronous from section to section. In this aspect this "lago-mare" biofacies is more similar with a Paratethyan biofacies. Within the gypsum bearing region "lago-mare" biofacies is focused in the latest Messinian only, in this aspect it could be called "Tethyan lago-mare' biofacies.

KEY WORDS: Biostratigraphy, Messinian, Foraminifera, Ostracods, "Lago- mare” Biofacies-Ionian Zone.

\section{INTRODUCTION}

In 1994, Prillo and Hasanaj gave information on the presence of "lago-mare" biofacies in the Durres region.

Later Prillo and Kumati (1996) based on the re-examination of foraminifera and ostracodes of several previously sampled sections (Dalipi et al, 1974; Prillo, 1981) gave a more complete regarding late Messinian "lagomare" biofacies. However many geologists of our country the conglomeratic beds occurred along Miocene/ Pliocene boundary continued to consider them as Pliocene basal conglomerates. In order to explain their real stratigraphic position by Kumati et al. (1999) were carried out several sections cross-exposed Messinian sediments along all eastern and northern part of PAF. In this work concluded that in most cases above mentioned conglomeratic beds included in "lago-mare" biofacies and rare they represent Pliocene basal conglomerates.

\section{MESSINIAN BIOSTRATIGRAPHY OF SECTIONS STUDIED}

Here is given biostratigraphic description of Progem, Thartor, Kernukje and Durres sections (Fig. 1, 2, 3). These sections were carried out cross the general extension of late Miocene sediments, beginning from southeast to northwest. First Progem and Thartor are similar with each other as concerning their lithology and faunistic content. The both sections are devoid planktonic forams in their Messinian sediments.

However the stratigraphic distribution of benthonic forams biofacies and ostracode biozones were established by comparison using Mediterranean planktonic forams zonation (Iaccarino, 1985;Prillo and Hasanaj, 1994).

The biostratigraphic description of two other sections is given separate.

\section{TORTONIAN/MESSINIAN BOUNDARY OF PROGEM AND THARTOR SECTIONS(FIG. 1, 2)}

The both sections were sampled close to marked organic limestone horizon. Only first samples (Progem 214) and (Thartor 226) contain planktonic foram which document the entry into late Tortonian, Globigerinoides extremus Zone. In the both sections all their rest part is represented only by benthonic fauna like Ammonia 


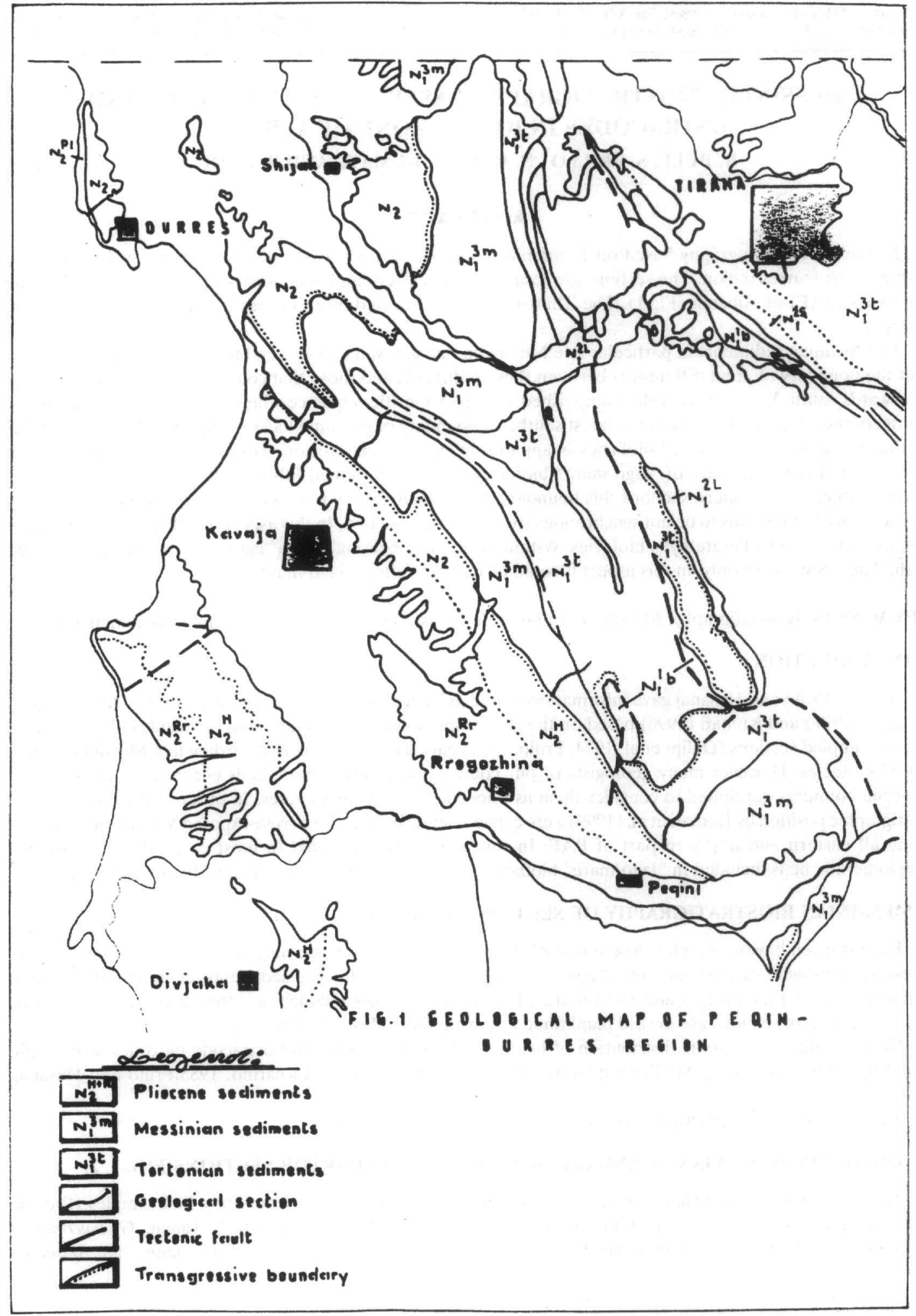




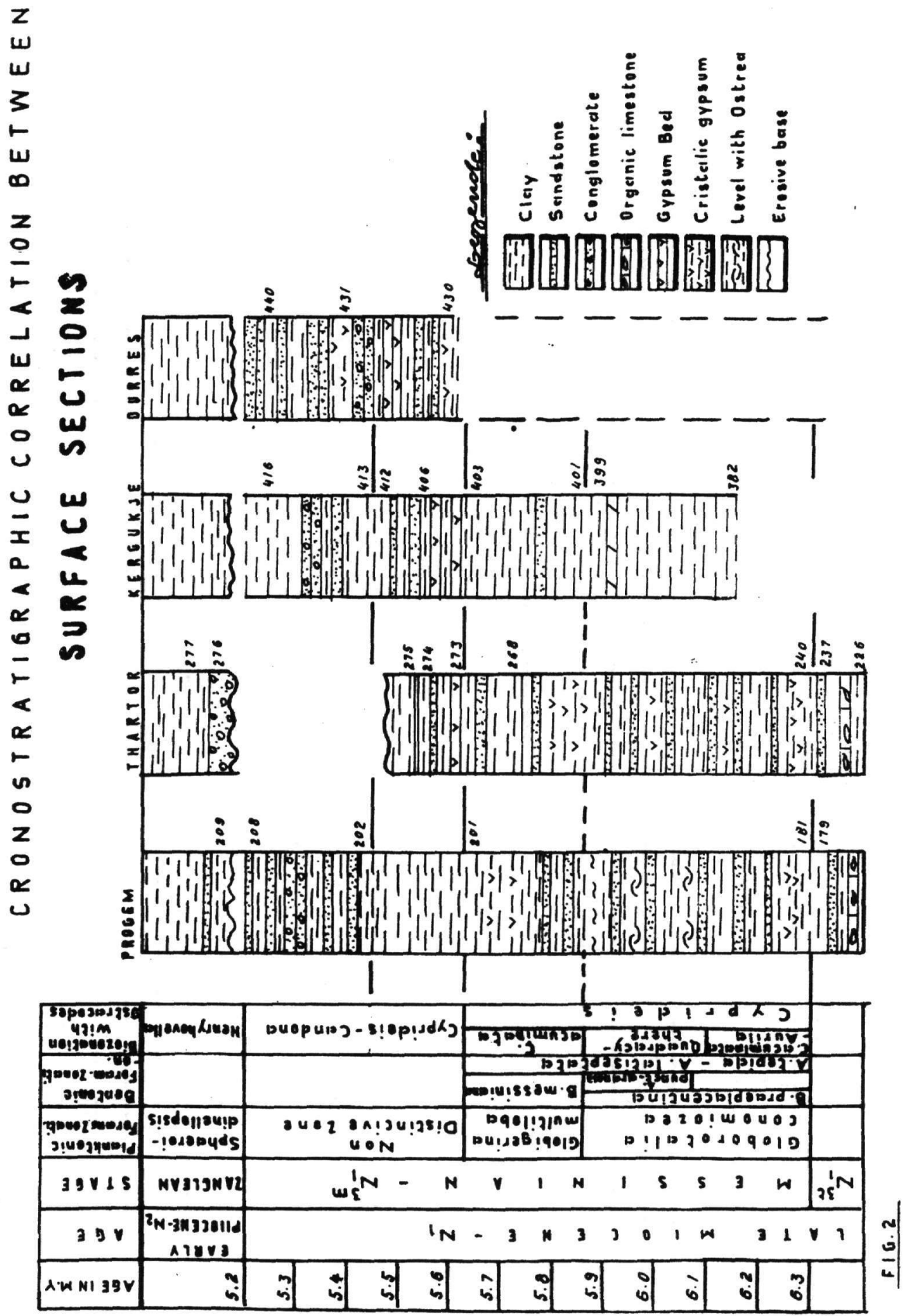


w

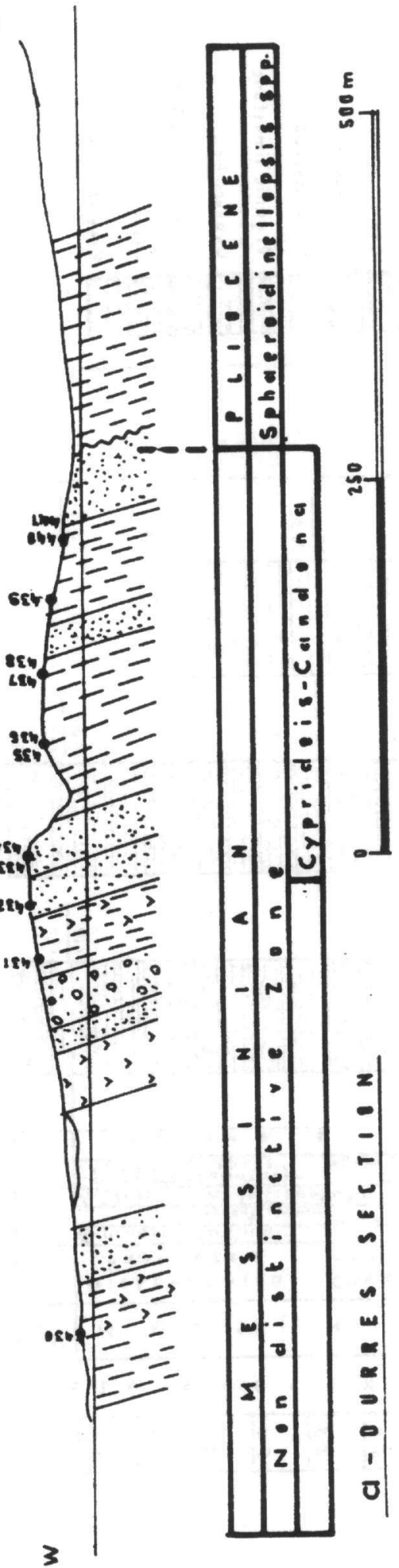

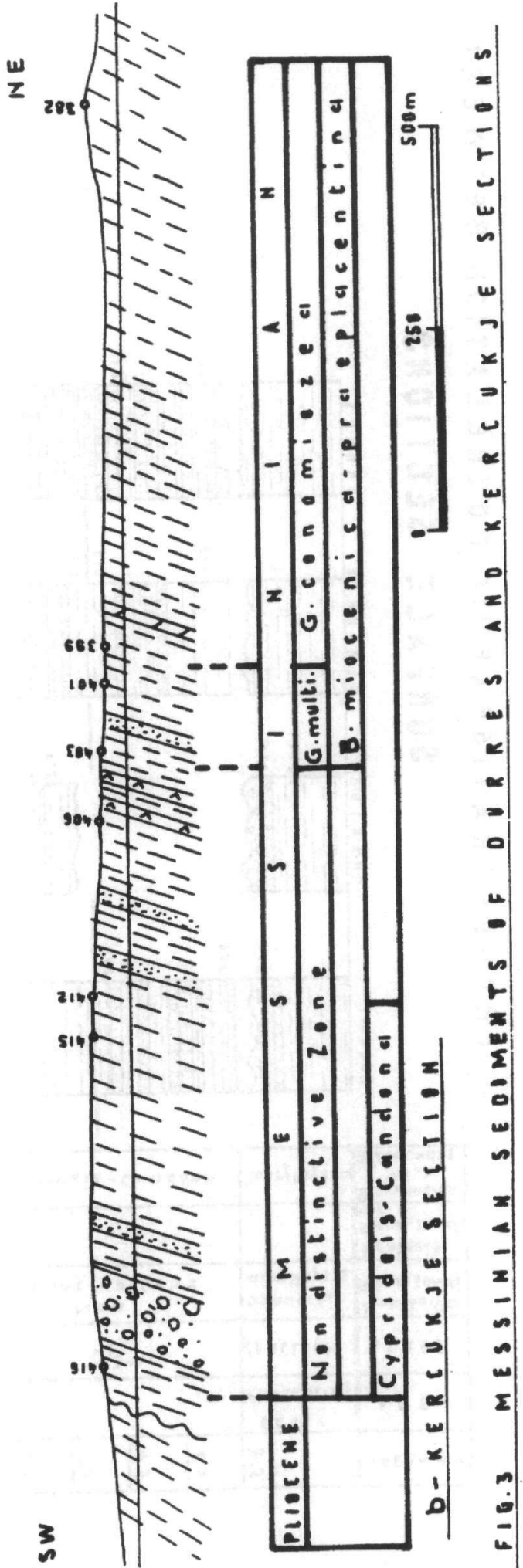


inflata frequent biofacies (Prillo et Kumati, 1996) and Cytheridea acuminata s.l.-Buntonia Zone (Ostracoda).

\section{Globorotalia conomiozea Zone}

Under the existing conditions, the latest Tortonian and all Messinian sediments are characterized by shallow, without planktonic foram sediments. They represented by the prevailing thick to massive sandstones alternating with clay layers, which in most of cases contain Oyster banks. In first samples of this interval, Progem 181 and Thartor 240 and by its end, Progem 200 and in particular Thartor 258 were found a lot of gypsum crystals. Here is difficult to bring at the same biostratigraphic level benthonic data with planktonic ones. Taking into consideration data of the present study sections and those of previous study, which contain as benthos and plankton, here is given an interval more or less equivalent with $G$. conomiozea Zone that corresponds with range distribution of Ammonia tepida-Ammonia latiseptata also it characterized by Cyprideis dominant biofacies. In Thartor by the end of this biofacies an organic limestone-sandstone level with Ammonia punctato-granosa etc. occurs. This level, which does not occurred in Progem section, apparently demonstrates the beginnings of differences in sedimentary basin from section to section.

\section{Globigerina multiloba Zone}

In Progem, this zone or its equivalences could not be established. In Thartor it is not well documented from sample 264 to 274 and it represents a preevaporitic sequence characterized by prevailing blue-grey unstratified clays and clayey marls. Here these clays contain very rare planktonic foram represented by very small Globigerina quinqueloba, G. cf. multiloba and reworked foram like Globorotalia mayeri, Globoquadrina dehiscens etc.

\section{Non - Distinctive Zone}

Under this definition we understand all late Messinian sediments, which, do not contain any index fossil and are usually very poor in fauna, which along their extension are replaced by gypsum blocks, which also occurred close to Pliocene basal conglomerates. In contrast, in Progem such a zone has a considerable thickness starting from sample 202 to 208 reaching over $250 \mathrm{~m}$ thickness. Its lower part represented by blue-grey to reddish clays and marls, while its middle part represented by a marker horizon over $10 \mathrm{~m}$ thickness with conglomerate and massive sandstone which previously considered as Pliocene basal conglomerates. Now it is included in so-called "lago-mare" biofacies and apparently it represents the latest Messinian "continental" transgression (Cita et al., 1980). Higher up, again occur grey unstratified clays without fauna which in their upper part passes into stratified clays alternating with thin siltstone and sandstone layers. Here in sample 208 are found frequently Cyprideis and pelecypods. At the beginning of this zone, sample 202 also was found very rare Candona. In sample nr.209 (5m above sample nr.208) documented Pliocene Sphaeroidinellopsis Acme zone, without remarkable horizon at Miocene/Pliocene boundary of Progem section.

\section{Globorotalia conomiozea zone, in Kerqukje section (Fig. 2, 3)}

This is the only surface section in PAF, where well exposed deep-sea sediments of the Messinian in age. It could be used as type-section in Albania for Messinian stage if its lower boundary would not be tectonic (Fig. 2, 3).

Its lithology is represented by prevailing blue-grey unstratified clays and clayey marls. These sediments are generally abundant in planktonic and benthonic forams, however $G$. conomiozea rare occurs.

\section{Globigerina multiloba Zone}

This zone starts from sample $\mathrm{nr}, 400$ to 403 . Its lithology represents a preevaporitic sequence similar with Tripoli Fm. in Italy, and characterized by prevailing grey unstratified marls which in their lower part (with exception of samples 398, 399 that not contain any fauna) are usually more abundant in planktonic than in benthonic foram, and in contrary occur in their upper part which may be also very poor in fauna indicating probably for entry in next successive zone.

\section{Non - Distinctive Zone}

As above-mentioned, such a zone is equivalent with Non-Distinctive zone of Iaccarino (1985). In our case its lower boundary starts from sample nr. 404 to 411 . All these samples are rich in gypsum crystals and without fauna. In this zone was also included the next interval from sample 412 to 416 . Its lower part is represented by 
grey to dark unstratified marls, which contain very rare Cyprideis. The middle part of this interval is represented, as Progem section, by a marker thick conglomerate-massive sandstone horizon over $10 \mathrm{~m}$ thickness. Higher up the interval is represented again by grey unstratified marls, rich in Cyprideis and pelecypods. This entire interval seems to be characterized by non-marine sediments of "lago-mare" biofacies, which according to Kumati et al. 1999 belong to Candona-Cyprideis zone.

\section{Durres section (Fig. 2, 3)}

In this surface section are exposed almost only sediments of Non-Distinctive zone (Kumati et al. 1999) and their Miocene/Pliocene boundary. The older sediments of Messinian in Durres are documented by some boreholes drilled along today Adriatic coast.

\section{Non - Distinctive Zone}

It starts from sample 430 to 441 . This entire zone here can be divided in two intervals. First starts from Adriatic coast to base of conglomeratic horizon and represented by alternating thin clay and siltstone layers which often contain also gypsum crystals and at the top of this interval a gypsum bed with maximal thickness 1.5 occurs. Close to this bed here starts next interval, which ends with ending of entire Messinian sediments. In its lower part represented by conglomerate massive sandstone horizon and gypsum crystals (sample 431). The rest part of this interval represented by grey unstratified clays in its lower part. Higher up the clays pass into alternating thin siltstone and thicker sandstone and again in its uppermost part grey to reddish unstratified marls occur which often contain Cyprideis and pelecypods. This entire interval, over 250m thickness previously was given Pliocene in age. Present Miocene/Pliocene boundary is undistinguishable lithologically, but well determined thanks to the presence of Sph. A. zone prior to first appearance of Globorotalia margaritae.

\section{CONCLUSIONS}

The northwestern part of studies region is characterized by the presence of a late Messinian gypsum bearing Formation the ending of which could be used as the lower boundary of so-called "lago-mare" biofacies. Here this biofacies can be recognised owing to the frequent presence of Cyprides genus or Cyprideis-Candona association. Also in all gypsum bearing sections of this part of the region is interesting the presence of a thick conglomerate-sandy unit at different levels within "lago-mare" biofacies. Such a unit is also occurred in the southeastern, without gypsum part of the region. Here is difficult to determine the lower boundary of Tethyan "lago-mare" biofacies because Cyprideis or Cyprideis-Candona associations and conglomerate-sandy unit could be also found in the middle or lower part of Messinian sediments, which do not contain any gypsum bed.

\section{REFERENCES}

CITA, M.B., SCHILLING, A.V. and BOSSIO, A. 1980 - Stratigraphy and Paleoenvironment of the Cuevas del Almanzora section (Vera Basin, Spain)

Riv.Ital.Paleont. 86, n.1, p. 215-240

DALIPI, H., NASTO, Th., DALIPI, V., dhe PRILLO S. 1974 - Stratigrafia dhe paleogjeografia e depozitimeve te Miocenit mesem, Miocenit te siperm dhe Pliocenit ne UPA. Fondi i ING Fier

IACCARINO, S. 1985 - Mediterranean Miocene and Pliocene planktonic foraminifera Plankton Stratigraphy. Cambridge University Press. p. 283-314

PRILLO, S. 1981 - Biostratigrafia e depozitimeve te Neogenit ne Ultesiren e Tiranes dhe ne UPA ne baze te studimit te fossileve Ostrakode ne depozitimet e Neogenit. Nafta dhe Gazi, nr. 1, Fier 1981.

KUMATI, Ll., PRILLO, S. dhe BULI, K. 1999. - Deshifrimi stratigrafik i depozitimeve detare dhe liqenoree te Messinianit ne baze te Ostrakodeve ne rajonin Vlore-Durres. Fondi i ING Fier

PRILLO, S.\& HASANAJ, L. 1994 - Studimi kompleks biostratigrafik i depozitimeve te Miocenit mesem dhe te siperm, per konkretizimin e kateve Langhian, Serravallian, Tortonian e Messinian sipas stratotipeve te Mesdheut (unpublished).

PRILLO, S. \& HASANAJ, L. 1999 - Biostratigrafia the interpretime paleoekologiike per depozitimet e Pliocenit ne Shqiperi. Fondi ING Fier.

PRILLO, S. \& KUMATI Ll. 1996 - The stratigraphic and paleoecological significance of the Bolivinitidae from the Serravallian to Pliocene sediments from Durres to Lushnja area (unpublished). 